\title{
Traits selection criteria for genetic improvement of grain and leafy Amaranth (Amaranthus
} spp) using Principal Component Analysis

Francis A. Showemimo*(D), Miriam A. Soyombo, Julius O. Amira and Justina B.O. Porbeni

Address:

Department of Plant Breeding and Seed Technology, College of Plant Science and Crop Production, Federal University of Agriculture, Abeokuta Nigeria

*Corresponding author: Showemimo, F.A, showfa20002@yahoo.com

Received:02.03.2021; Accepted: 20.05.2021; Published: 01.06.2021

$\underline{10.21608 / \text { ejar.2021.65946.1089 }}$

\section{ABSTRACT}

Grain Amaranths are important nutritional vegetables in the world for their grains and leaves. Twelve grain Amaranth accessions were evaluated for their performances using randomized complete block design with 3 replications in the cropping seasons of 2016 and 2017 to measure variability, Classify the accessions and select outstanding genotypes. Analysis of Variance and accessions performances revealed significant variability among the grain Amaranths. Phenotypic variances were higher in magnitude than genotypic variance for all the traits studied. The high genetic advance was obtained for all the characters except 1000 grain weight (23.61). The genotypic coefficients of variations were lower than the phenotypic coefficient of variations. Heritability ranged from $41.08 \%$ for grain yield/plot to $62.18 \%$ for plant height at flowering. Grain yield was positive and highly significantly correlated with 1000 grain weight, leaf area but significantly correlated only with leaf length and leaf width. The Principal Component Analysis (PCA) revealed four main components of variations representing $78.06 \%$ of the total variability among the 12 -grain amaranth accessions. The PCA identified all the 12 traits as strongly correlated with the three principal components. PC1 is well-correlated with plant height at flowering, stem girth, a number of leaves, plant height at maturity, leaf width, leaf length, leaf area and petiole length. The bi-plot analysis classified the accession NG/AA/03/11/010, NGB 01259, and NGB 0127 as having good leaf yield and desired leaf traits, Accession NHGB/09/108, NG/AO/08/04 and NGB 01261 were grouped as better grain yield with good yield attributes, while accession NGB 01234, NHGB 09/09 and NHAC3 are good dual-purpose accessions having good grain and leaf yield.

Keywords: Accessions, classification, heritability, variability, yield, grain and leaf amaranth

\section{INTRODUCTION}

Amaranths are non-grasses and are called pseudo-cereals because of their similarities to cereals in flavor and cooking. The genus; Amaranth has about 60 species worldwide is characterized by a high degree of diversity and a wide spectrum of adaptability to different agro-ecological conditions (Snezana et al., 2012). The edible species of the genus Amaranthus commonly found in Nigeria are A. cruentus, $A$. dubius, $A$ caudatus and $A$. hypochondriacus. Amaranthus cruentus is a Mexican and Guatemalan species. It is useful both as a grain and as leafy vegetable. A. cruentus is a tall annual herb, at times referred to as red, blood or purple amaranth. The grain types have white grains, while the leafy or wild types have dark grains and it flowers under a wider range of day length (Coastea and Demason, 2001; Amfo and Ali, 2021). A. cruentus is a broad leaf with protein rich edible grains. The proteins have a high sulphur containing essential amino acids (Lysine, Methionine and Cysteine), which makes it better than cereals crops. Its importance is in the quality of the leaves and tender stem for food, high biocompatibility, nutritional value, antioxidants, mineral contents and low cost of production and sale than cereal crops (FAO 2020 and Alam, et al., 2021). The grains are more nutritious than the leaves, the grains contains $13.5-18.3 \%$ crude protein, $60.5-65.8 \%$ carbohydrate, 2.7-4.5\% total ash, 6.6-9.1\% crude fat, 3.1-5.3\% crude fiber, 7.1-9.2\% moisture content and 10.2-17.6 (MJ Kg-1) energy value (Saunder and Becker, 1983). Amaranthus cruentus along with other vegetable ingredients such as pepper, "egusi", melon, are used to make soup (Olufemi et al., 2003; Alegbejo, 2013). It is cultivated and consumed all over Nigeria and it is rated among the top five of the most important national vegetables (Babalola et al., 2010). The average consumption of $A$. cruentus leaves in the tropics is estimated at about $20-25 \mathrm{~g}$ per head per day which is below their recommended rate of $100 \mathrm{~g}$ per head per day (Olufolaji, 1996). Protein from $A$. cruentus leaves provides as much as $25 \%$ of the daily protein intake during the harvest season. It is grown all the year round (Denton and Olufolaji, 2000).

Grain amaranth is reported to be drought-tolerant compared to most vegetables. One trait that helps it tolerate extremely dry conditions is its ability to wilt temporarily and then revive after rainfall occurs. The crop cannot withstand waterlogging as it has a relatively low capacity for water consumption. The exposure of the plant to severe drought induces early flowering and halts the production of leaves (Nwangburuka et al., 2011; Snezana et al., 2012). Despite the economic importance of $A$ cruentus to human and animal diets and other industrial uses, there is limited information on the improvement of grain amaranth. Therefore, it is necessary to understand the agromorphological characteristics of accessions of grain amaranth and assess the genetic information that will help in selection of the best genotypes that can be used for future breeding programme. The objectives of this study are to obtain the genetic components of variance, heritability and genetic advance controlling the agro-morphological traits of accessions of grain amaranth, to determine the association and percentage contribution of each agronomic trait to grain yield.

\section{MATERIALS AND METHODS}

\section{Experimental material:}

Twelve new collections or accessions of grain amaranth sourced from the National Horticultural Research Institute (NIHORT), Ibadan, were used in this study. They include: NGB 01274, NG/AA/03/11/010, NGB 01234, NHGB 09/09, NHAc 3,NGB 01259,NGB 01271, NHGB/09/108,NGB 012131, NG/AO/11/08/039,NG/AO/08/04 and NGB 01261.

\section{The experimental site, design and cultural practice:}

The field experiment was carried out at the Teaching and Research Farms, Federal University of Agriculture, Abeokuta, Nigeria (Latitude $7.1^{\circ} \mathrm{N}$, longitude $3.2^{\circ} \mathrm{E}$ and altitude $76 \mathrm{~m}$ ) for 2 cropping season April to August 2016 and 2017. The average rainfall for the cropping in 2016 was $1020 \mathrm{~mm}$ and $1018 \mathrm{~mm}$ for 2017 , the average temperature for the cropping period was $26^{\circ} \mathrm{C}$ in 2016 and $27^{\circ} \mathrm{C}$ in 2017 , the soil type was sandy loam Alfisol in a humid climatic condition. Land was mechanically ploughed and harrowed, beds were made using a hoe. Grains of 
twelve varieties were sown in a Randomized Complete Block Design (RCBD) with three replications using plant spacing of $35 \mathrm{~cm} \times 50 \mathrm{~cm}$ intra and inter-row spacing. The area of each plot is $3.5 \mathrm{~m}^{2}(7 \mathrm{~m}$ row and $0.5 \mathrm{~m}$ inter-row) with 3 rows per accession of 20 plants per row. All other cultural practices were carried out as at when due.

\section{Data collection:}

The following data were collected on ten randomly selected plants per plot: Plant height at maturity $(\mathrm{cm})$, Number of leaves at maturity, Leaf length at maturity $(\mathrm{cm})$, Leaf width at maturity $(\mathrm{cm})$, Leaf area at maturity $\left(\mathrm{cm}^{2}\right)$, Stem girth at maturity $(\mathrm{cm})$, Number of branch per plant, Petiole length $(\mathrm{cm})$, Days to 50\% flowering, Plant height at flowering $(\mathrm{cm}), 1000$ grain weight $(\mathrm{g})$ and Grain yield per plot $(\mathrm{g})$.

\section{Statistical analysis:}

Data collected were subjected to Analysis of Variance (ANOVA) and mean separation was done using Tukey's Statistic Significance test ( $T_{0}$ ) at $5 \%$ probability levels, Pearson Correlation Coefficient Analysis was carried out to determine character association between the variables, Principal Component Analysis (PCA) and Bi-plots based on significant traits within the Principal Component (PC) were determined on the evaluated variables (Yan and Kang, 2003; SAS, 2008). Heritability estimates of the characters were computed according to the formula as described by Allard (1960) as follow:

$\mathrm{h}^{2} \mathrm{bs}=\left[\left(\sigma_{\mathrm{g}}^{2}\right) /\left(\sigma_{\mathrm{p}}^{2}\right)\right] \times 100$ Equation 1

Where: $h^{2}=$ heritability in broad sense; $\sigma^{2}=$ Genotypic variance; $\sigma^{2}=$ Phenotypic variance.

Phenotypic variance $\left(\delta^{2}\right)$, Genotypic variance $\left(\delta^{2} \mathrm{~g}\right)$, Environmental variance $\left(\delta^{2} \mathrm{e}\right)$, Phenotypic Coefficients of Variation (PCV), Genotypic Coefficients of Variation (PCV) and Genetic gain (GA) were calculated by the formula below as suggested by Burton (1952), Falconer (1981), Singh and Chaudhary (1985)

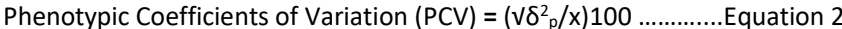

Genotypic Coefficients of Variation $(\mathrm{PCV})=\left(\mathrm{V} \delta^{2} \mathrm{~g} / \mathrm{x}\right) 100 \ldots \ldots \ldots \ldots . .$. Equation 3

Where: $\delta^{2}{ }_{p}=$ Phenotypic variance, $\delta^{2}=$ Genotypic variance and $\mathrm{x}=$ Grand mean of a character

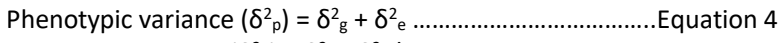

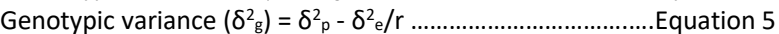

Environmental variance $\left(\delta^{2} \mathrm{e}\right)=\mathrm{MSe} / \mathrm{r}$

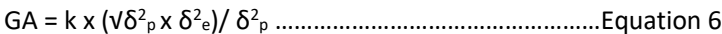

Where: $\mathrm{GA}=$ Expected genetic advance

$\mathrm{K}=$ Standardized selection differential at $5 \%$ intensity $(\mathrm{k}=2.063)$

$\delta^{2}{ }^{2}=$ Phenotypic variance

$\delta_{\mathrm{g}}^{2}=$ Genotypic variance

\section{RESULTS}

\section{Variability:}

Mean squares values from analysis of variance (ANOVA) for agronomic characters of the twelve accessions of amaranth (Table 1) revealed that the varietal effect shows high significance in plant height at maturity, no of branches, leaf width, leaf length, leaf area, petiole length and1000 grain weight. The replicate effect was also significant for all plant characters measured except for number of leaves, leaf width, petiole length, 1000 grain weight and grain yield/plant, while the yearly effect was not statistically different for all the traits studied.

Mean values of agronomic parameters evaluated in twelve accessions of amaranth evaluated for yield and related traits (Table 1) showed significant differences $(P \leq 0.05)$ among amaranths accessions used in this study for days to flowering, plant height at flowering, number of leaves, plant height at maturity, leaf width, leaf length, leaf area and petiole length. While highly significant difference (P $\leq 0.05$ ) was obtained for stem girth, number of branches, 1000 grain weight and grain yield/plot. The least CV was $5.3 \%$ for the number of leaves and the largest was for leaf length (31.4\%). The performance of grain Amaranth accessions as seen in Table 1, show that NGB 01234, NHGB 09/09, NHAC3, NHGB/09/108, NG/AO/08/04 and NGB 01261 has grain yield above grand genotypic yield/plot (1.60g). NGB 01234 (2.06g), NHGB 09/09 (2.22g), NGB 01261 (2.24g), NG/AO/08/04 (2.36g) and NHGB/09/108 (2.56g) produced the highest grain yield, and the least yield was obtained from NGB 1216 (0.21g). Five accessions (NG/AA/03/11/010, NGB 01234, NHGB 09/09, NHGB/09/108 and NG/AO/08/04) had a higher 1000 grain weight than the remaining 7 accessions. The following accession NGB 01274, NG/AA/03/11/010, NGB 01259, NGB 0127, and NHGB/09/108 has a higher number of leaves than the genotypic mean (19.30), the highest number of leaves was recorded for accession NGB 0127(26.27), followed by NGB 01259 (25.97) and the least (13.50) was recorded for NG/AO/11/08/039. Accession NGB 0127 had the highest leaf area value of $120.40 \mathrm{~cm}^{2}$, followed by accession NHAc3 $\left(101.65 \mathrm{~cm}^{2}\right)$ while NG/AO/11/08/039 had the least value of $47.63 \mathrm{~cm}^{2}$.

\section{Performance Analysis:}

Petiole length, leaf length, leaf width and plant height at maturity had differential responses by the grain amaranth accessions, the accessions that performed better than other accessions for these characters are NGB 01274, NG/AA/03/11/010, NGB 01234, NHGB 09/09, NHAC3, NGB 01259, NGB 0127, NHGB/09/108(Petiole length only), NGB 012131 (Plant height only) and NG/AO/08/04(Leaf width only). NHAC3, NHGB/09/108, NGB 012131, 10 and NG/AO/08/04 flowered later than the genotypic mean of 55days. Four-grain amaranths had a short plant height than the remaining 8 accessions at flowering time. NGB $01274(3.75 \mathrm{~cm}), \mathrm{NG} / \mathrm{AA} / 03 / 11 / 010(3.94 \mathrm{~cm}), \mathrm{NGB} 01234$ $(3.58 \mathrm{~cm}), \mathrm{NHGB} 09 / 09(3.67 \mathrm{~cm}), \mathrm{NGB} 0127(3.67 \mathrm{~cm})$ and NGB $012131(3.51 \mathrm{~cm})$ has bigger stem girth than the genotypic mean $(3.34 \mathrm{~cm})$ 
Table 1. Mean values, mean square, coefficient of variation for agronomic characters of 12 accessions of grain amaranth across 2 years

\begin{tabular}{|c|c|c|c|c|c|c|c|c|c|c|c|c|}
\hline Accession & $\begin{array}{c}\text { Days to } 50 \% \\
\text { Flowering }\end{array}$ & $\begin{array}{l}\text { Plant height at } \\
\text { flowering } \\
\text { (cm) }\end{array}$ & $\begin{array}{l}\text { Stem } \\
\text { girth } \\
\text { (cm) }\end{array}$ & $\begin{array}{l}\text { No of } \\
\text { leaves }\end{array}$ & $\begin{array}{l}\text { Plant height } \\
\text { at maturity } \\
(\mathbf{c m})\end{array}$ & $\begin{array}{c}\text { No of } \\
\text { branches }\end{array}$ & $\begin{array}{c}\text { Leaf } \\
\text { width } \\
(\mathrm{cm})\end{array}$ & $\begin{array}{l}\text { Leaf } \\
\text { Length } \\
(\mathrm{cm})\end{array}$ & $\begin{array}{l}\text { Leaf Area } \\
\qquad\left(\mathrm{cm}^{2}\right)\end{array}$ & $\begin{array}{l}\text { Petiole } \\
\text { Length } \\
\text { (cm) }\end{array}$ & $\begin{array}{c}1000 \\
\text { grain } \\
\text { weight } \\
\text { (g) }\end{array}$ & $\begin{array}{c}\text { Grain } \\
\text { yield/Plot } \\
\text { (g) }\end{array}$ \\
\hline NGB01274 & $50.00 \mathrm{bc}$ & $149.24 a$ & $3.75 a$ & $20.20 \mathrm{ab}$ & $37.44 a$ & $3.16 b c$ & $6.76 \mathrm{~b}$ & $13.47 \mathrm{~b}$ & $91.77 \mathrm{~b}$ & $8.13 a$ & $0.30 \mathrm{~b}$ & $0.85 c$ \\
\hline NG/AA/03/11/010 & $48.67 c$ & $143.37 a$ & $3.94 a$ & $23.63 a$ & $38.43 a$ & $3.77 b c$ & $6.65 b$ & $13.70 \mathrm{~b}$ & $91.96 b$ & $7.25 a$ & $0.35 b$ & $1.43 \mathrm{~b}$ \\
\hline NGB 01234 & $48.00 c$ & 139.59ab & 3.58ab & $18.73 b$ & $37.36 a$ & $4.80 \mathrm{a}$ & $6.39 \mathrm{~b}$ & $13.18 b$ & $85.72 b$ & $5.07 \mathrm{~b}$ & $0.52 a$ & $2.06 a$ \\
\hline NHGB 09/09 & $53.33 b$ & $124.26 \mathrm{c}$ & $3.67 a$ & $16.47 b$ & $37.12 \mathrm{a}$ & $3.70 b c$ & $6.44 \mathrm{~b}$ & $12.3 \mathrm{bc}$ & $81.11 b$ & $5.32 \mathrm{~b}$ & $0.49 a$ & $2.22 \mathrm{a}$ \\
\hline NHAC3 & $63.00 a$ & $144.97 a$ & $3.18 \mathrm{~b}$ & $16.60 \mathrm{~b}$ & $30.97 b$ & $2.37 \mathrm{~d}$ & $6.66 \mathrm{~b}$ & $15.53 a$ & $101.65 \mathrm{~b}$ & $4.72 \mathrm{bc}$ & $0.28 \mathrm{~b}$ & $1.83 \mathrm{~b}$ \\
\hline NGB 01259 & $51.33 b c$ & $128.62 \mathrm{bc}$ & $3.20 \mathrm{~b}$ & $25.97 a$ & $34.25 a$ & $5.03 a$ & $6.75 b$ & $13.52 b$ & $95.04 b$ & $4.34 c$ & $0.30 \mathrm{~b}$ & $0.91 \mathrm{c}$ \\
\hline NGB 0127 & $54.67 b$ & $132.05 \mathrm{~b}$ & $3.67 a$ & $26.27 a$ & $36.21 a$ & $3.70 b c$ & $8.75 a$ & $13.37 \mathrm{~b}$ & $120.40 a$ & $5.56 \mathrm{~b}$ & $0.30 \mathrm{~b}$ & $1.10 \mathrm{bc}$ \\
\hline NHGB/09/108 & $58.67 a b$ & $129.22 b c$ & $2.85 b c$ & $23.93 a$ & $27.44 \mathrm{bc}$ & $3.14 b c$ & $6.30 \mathrm{~b}$ & $12.36 \mathrm{bc}$ & $79.94 c$ & $5.19 \mathrm{~b}$ & $0.32 \mathrm{~b}$ & $2.56 a$ \\
\hline NGB 012131 & $61.00 a$ & $127.49 \mathrm{c}$ & 3.51ab & $13.53 \mathrm{bc}$ & $38.41 a$ & $2.65 \mathrm{~d}$ & $5.75 b c$ & $12.33 \mathrm{bc}$ & $71.43 \mathrm{bc}$ & $4.86 \mathrm{bc}$ & $0.29 b$ & $1.16 \mathrm{bc}$ \\
\hline NG/AO/11/08/039 & $60.33 a$ & $113.59 \mathrm{~d}$ & $2.80 c$ & $13.50 \mathrm{bc}$ & $23.76 c$ & $2.75 \mathrm{~d}$ & $4.72 \mathrm{~d}$ & $10.02 d$ & $47.63 d$ & $3.68 c$ & $0.29 \mathrm{~b}$ & $0.42 c$ \\
\hline NG/AO/08/04 & $62.00 \mathrm{a}$ & 104.38de & $3.22 \mathrm{bc}$ & $17.47 \mathrm{~b}$ & $29.15 b$ & $4.22 a b$ & $6.57 \mathrm{~b}$ & $11.78 c$ & $85.97 \mathrm{~b}$ & $4.27 b c$ & $0.3 \mathrm{~b}$ & $2.36 a$ \\
\hline NGB 01261 & $53.67 b$ & $93.01 \mathrm{e}$ & $2.71 \mathrm{c}$ & $15.27 b$ & $24.27 c$ & $3.03 c$ & $5.98 \mathrm{c}$ & $11.15 c$ & $70.44 c$ & $3.85 c$ & $0.21 b c$ & $2.24 a$ \\
\hline Mean Square & $187.63^{*}$ & $862.20^{*}$ & $4.05^{* *}$ & $94.41 *$ & $292.10^{*}$ & $12.10^{* *}$ & $10.54^{*}$ & $15.94^{*}$ & $970.87^{*}$ & $5.19^{*}$ & $2.03 * *$ & $11.52^{* *}$ \\
\hline CV (\%) & 14.70 & 13.00 & 16.30 & 5.30 & 16.40 & 19.80 & 29.90 & 31.40 & 20.50 & 24.50 & 28.10 & 30.60 \\
\hline Grand Mean & 55.39 & 127.48 & 3.34 & 19.30 & 32.90 & 3.53 & 6.48 & 12.73 & 85.26 & 5.19 & 0.33 & 1.60 \\
\hline
\end{tabular}

$*{ }^{* *}$ is significance at $\mathrm{P} \leq 0.05$ and $\mathrm{P} \leq 0.01$, Means followed by similar alphabets within same column were not significantly different from one another according to Tukey's Statistic tests at $5 \%$ probability level 


\section{Genetic study:}

Genotypic mean, range, Genotypic and Phenotypic variance, Genetic advance, Coefficient of variation and broad-sense heritability are presented in Table (2). The phenotypic variances are higher in magnitude than the genotypic variance. The highest genetic advance was obtained for number of leaves (109197.49) and the least value (23.61) was obtained for 1000 grain weight. High phenotypic coefficient of variance (77.51) for grain yield/plot, 67.7 for 1000 grain weight, 55.51 for number of branches and the least value of 21.95 was obtained for Days to flowering. The genotypic coefficient of variation was lower than the phenotypic coefficient of variation. The broad-sense heritability ranged from $41.08 \%$ for grain yield/plot to $62.18 \%$ for plant height at flowering.

Table 2. Components of variance, genetic advance and heritability estimate of 12 traits of grain amaranth accessions

\begin{tabular}{|c|c|c|c|c|c|c|c|c|}
\hline Characters & Mean & Range & $\begin{array}{l}\text { Genotypic } \\
\text { Variance }\end{array}$ & $\begin{array}{l}\text { Phenotypic } \\
\text { Variance }\end{array}$ & $\begin{array}{l}\text { Genetic } \\
\text { Advance }\end{array}$ & $\begin{array}{l}\text { Genotypic } \\
\text { Coefficient } \\
\text { of Variation }\end{array}$ & $\begin{array}{l}\text { Phenotypic } \\
\text { Coefficient } \\
\text { of Variation }\end{array}$ & $\begin{array}{l}\text { Heritability } \\
\text { BS (\%) }\end{array}$ \\
\hline $\begin{array}{l}\text { Days to } 50 \% \\
\text { flowering }\end{array}$ & 55.39 & $48-63$ & 87.63 & 147.86 & 1268.45 & 16.90 & 21.95 & 59.27 \\
\hline $\begin{array}{l}\text { Plant height at } \\
\text { flowering }(\mathrm{cm})\end{array}$ & $\begin{array}{l}127.4 \\
8\end{array}$ & $\begin{array}{l}93.01- \\
149.24\end{array}$ & 862.20 & 1386.57 & 4075.06 & 23.03 & 29.21 & 62.18 \\
\hline Stem girth $(\mathrm{cm})$ & 3.34 & $2.71-3.94$ & 0.50 & 0.95 & 9028.31 & 21.17 & 29.18 & 52.63 \\
\hline No of leaves & 19.30 & $13.50-26.27$ & 64.41 & 107.79 & 109197.49 & 41.53 & 53.79 & 59.76 \\
\hline $\begin{array}{l}\text { Plant height at } \\
\text { maturity }(\mathrm{cm})\end{array}$ & 32.90 & $23.76-38.43$ & 92.12 & 163.64 & 1132.24 & 29.17 & 38.88 & 50.29 \\
\hline No of branches & 3.53 & $2.37-5.03$ & 2.10 & 3.84 & 18861.94 & 41.07 & 55.51 & 54.69 \\
\hline Leaf width(cm) & 6.48 & $4.72-8.75$ & 2.54 & 5.03 & 199.34 & 24.59 & 34.61 & 50.50 \\
\hline $\begin{array}{l}\text { Leaf } \\
\text { length }(\mathrm{cm})\end{array}$ & 12.73 & $10.02-15.53$ & 5.94 & 10.01 & 330.43 & 19.15 & 24.85 & 59.34 \\
\hline Leaf area $\left(\mathrm{cm}^{2}\right)$ & 85.26 & $\begin{array}{l}47.63- \\
120.40\end{array}$ & 970.67 & 1811.96 & 4013.36 & 36.54 & 49.93 & 53.57 \\
\hline $\begin{array}{l}\text { Petiole } \\
\text { length }(\mathrm{cm})\end{array}$ & 5.19 & $3.68-8.13$ & 5.19 & 7.54 & 332.64 & 43.90 & 52.91 & 68.83 \\
\hline $\begin{array}{l}1000 \text { grain } \\
\text { weight(g) }\end{array}$ & 0.33 & $0.21-0.52$ & 0.03 & 0.05 & 23.61 & 52.49 & 67.76 & 60.00 \\
\hline $\begin{array}{l}\text { Grain } \\
\text { yield/plot(g) }\end{array}$ & 1.60 & $0.42-2.56$ & 1.52 & 3.70 & 139.07 & 77.06 & 77.51 & 41.08 \\
\hline
\end{tabular}

\section{Trait association:}

Table (3) shows the correlation coefficient matrix for 12 characters among the twelve accessions of grain amaranth. Grain yield was positive and significantly correlated with 1000 grain weight $(0.68)$, leaf area $(0.45),(0.40)$ and leaf width $(0.40)$. Leaf area was positive and highly significantly correlated with plant height at flowering, stem girth, number of leaves, plant height at maturity, leaf width and leaf length. Similarly, plant height at maturity was highly significant and positively correlated with plant height at flowering and stem girth, while it was significantly correlated with number of leaves. The stem girth of grain amaranth in this study was positive and highly significantly correlated with plant height at maturity (0.92), leaf length (0.65), leaf area (0.65), leaf width (0.56) and plant height at flowering $(0.46)$. 
Table 3. Correlation coefficient matrix of 12 accessions of grain amaranth across 2 years

\begin{tabular}{|c|c|c|c|c|c|c|c|c|c|c|c|c|}
\hline Characters & $\begin{array}{c}\text { Days to } 50 \% \\
\text { flowering }\end{array}$ & $\begin{array}{c}\text { Plant } \\
\text { height at } \\
\text { flowering } \\
\text { (cm) }\end{array}$ & $\begin{array}{c}\text { Stem } \\
\text { girth }(\mathrm{cm})\end{array}$ & $\begin{array}{l}\text { No of } \\
\text { leaves }\end{array}$ & $\begin{array}{c}\text { Plant } \\
\text { height at } \\
\text { maturity } \\
\text { (cm) }\end{array}$ & $\begin{array}{c}\text { No of } \\
\text { branches }\end{array}$ & $\begin{array}{c}\text { Leaf } \\
\text { width } \\
(\mathrm{cm})\end{array}$ & $\begin{array}{c}\text { Leaf } \\
\text { length } \\
(\mathrm{cm})\end{array}$ & $\begin{array}{c}\text { Leaf area } \\
\left(\mathrm{cm}^{2}\right)\end{array}$ & $\begin{array}{l}\text { Petiole } \\
\text { length } \\
(\mathrm{cm})\end{array}$ & $\begin{array}{l}1000 \text { grain } \\
\text { weight }(\mathrm{g})\end{array}$ & $\begin{array}{c}\text { Grain } \\
\text { yield/plot } \\
\text { (g) }\end{array}$ \\
\hline Days to $\mathbf{5 0 \%}$ flowering & 1 & $0.79 * *$ & 0.28 & -0.12 & 0.23 & $0.48^{* *}$ & 0.09 & 0.19 & 0.16 & -0.01 & -0.27 & 0.24 \\
\hline $\begin{array}{l}\text { Plant height at } \\
\text { flowering }\end{array}$ & & 1 & $0.53^{* *}$ & $0.35^{*}$ & $0.62^{* *}$ & 0.09 & $0.41^{*}$ & $0.52^{* *}$ & $0.47^{* *}$ & $0.62^{* *}$ & 0.08 & 0.01 \\
\hline Stem girth & & & 1 & $0.37^{*}$ & $0.92^{* *}$ & 0.23 & $0.56^{* *}$ & $0.65^{* *}$ & $0.65^{* *}$ & $0.46^{* *}$ & 0.05 & 0.27 \\
\hline No of leaves & & & & 1 & $0.39 *$ & $0.36^{*}$ & $0.49 * *$ & $0.38^{*}$ & $0.49 * *$ & 0.19 & -0.05 & -0.07 \\
\hline Plant height at maturity & & & & & 1 & 0.23 & $0.60^{* *}$ & $0.69 * *$ & $0.69 * *$ & $0.40^{*}$ & 0.06 & 0.12 \\
\hline No of branches & & & & & & 1 & 0.09 & 0.12 & 0.12 & -0.04 & -0.10 & 0.04 \\
\hline Leaf width & & & & & & & 1 & $0.61 * *$ & $0.95 * *$ & 0.26 & 0.01 & $0.40^{*}$ \\
\hline Leaf length & & & & & & & & 1 & $0.83^{* *}$ & 0.27 & 0.01 & $0.40^{*}$ \\
\hline Leaf area & & & & & & & & & 1 & 0.26 & 0.01 & $0.45 * *$ \\
\hline Petiole length & & & & & & & & & & 1 & 0.08 & -0.01 \\
\hline 1000 grain weight & & & & & & & & & & & 1 & $0.68^{* *}$ \\
\hline Grain yield/plot & & & & & & & & & & & & 1 \\
\hline
\end{tabular}


Traits and genotypic capture:

The PCA revealed that the first four principal axes (components) of variations representing $68.21 \%$ of the total variability among the 12 grain amaranth accessions. The three principal components explained $36.37,12.28$ and $10.10 \%$ of the total variance, respectively. These components represented $58.76 \%$ of the total variance components (Table 4). Strong correlations were observed between PCs and phenotypic traits (Table 4). PC1 is well-correlated with 8 traits; plant height at flowering, stem girth, number of leaves, plant height at maturity, leaf width, leaf length, leaf area and petiole length. PC2 is correlated with number of branches (0.60) and 1000 grain weight (0.52), while, PC3 has a strong association with days to $50 \%$ flowering (0.89) and grain yield/plot (0.70). PC4 is fairly correlated with Plant height at flowering, Leaf width and Leaf area. The PCA identified all the 12 phenotypic traits were strongly correlated with the three principal components.

Table 4. Principal component analysis of agronomic characters in Amaranthus spp

\begin{tabular}{|c|c|c|c|c|}
\hline Agronomic Characters & PC1 & PC2 & PC3 & PC4 \\
\hline Days to $50 \%$ flowering & 0.24 & 0.76 & 0.89 & 0.003 \\
\hline Plant height at flowering $(\mathrm{cm})$ & 0.69 & 0.30 & 0.22 & 0.33 \\
\hline Stem girth $(\mathrm{cm})$ & 0.86 & 0.03 & 0.04 & 0.18 \\
\hline Number of leaves & 0.54 & 0.08 & 0.48 & 0.10 \\
\hline Plant height at maturity $(\mathrm{cm})$ & 0.89 & 0.02 & 0.05 & 0.17 \\
\hline Number of branches & 0.26 & 0.60 & 0.37 & 0.21 \\
\hline Leaf width(cm) & 0.81 & 0.02 & 0.10 & 0.34 \\
\hline Leaf length(cm) & 0.84 & 0.03 & 0.09 & 0.19 \\
\hline Leaf area $\left(\mathrm{cm}^{2}\right)$ & 0.90 & 0.03 & 0.11 & 0.33 \\
\hline Petiole length(cm) & 0.48 & 0.47 & 0.23 & 0.29 \\
\hline 1000 grain weight(g) & 0.04 & 0.52 & 0.37 & 0.07 \\
\hline Grain yield /plot(g) & 0.39 & 0.35 & 0.70 & 0.12 \\
\hline Elgen values & 5.09 & 1.72 & 1.41 & 1.32 \\
\hline$\%$ of variance & 39.87 & 18.64 & 10.10 & 9.45 \\
\hline$\%$ of cumulative & 36.37 & 58.51 & 68.61 & 78.06 \\
\hline
\end{tabular}

Values with 0.30 and above were bolded had a significant contribution to variation

The bi-plot of genotypes based on their most significant or strongly correlated traits are presented in Fig 1, 2 and 3. The bi-plot of accessions in Fig 1, shows the plot of PC2 against PC1 and it grouped the 12 accessions into 4 quadrants A, B, C and D. Accessions in quadrant B and D have high grain yield and they flower early which is highly correlated with PC3, (Table 4) while 7 accessions in quadrants A and B have comparably better yield than accessions in quadrant C and D. Fig 2 is the bi-plot in the 12 accessions into four different quadrants based on grain yield and desired leaf traits as correlated with PC3 and PC1. Seven accessions of grain amaranth accession grouped in quadrant B and $D$ are characterized by high grain yield and excellent leaf traits (Number of leaves, Leaf width, Leaf length, Leaf area and Petiole length), thus, suggesting dual-purpose accessions. In Fig 3, associating number of branches and 1000grain weight (PC2) with days to 50\% flowering and grain yield (PC3) as seen in Table 4. Quadrants B and D having seven accessions are characterized by high grain yield and heavy 1000 grain weight, the 2 accessions in quadrant $A$ have better grain yield than the 3 accessions in quadrant $C$ and 2 accessions in quadrant D. Fig 4 and 5 are the representation of accession performances based on peculiar traits, the 3 accessions of grain amaranth; (NG/AA/03/11/010, NGB 01259, and NGB 0127) were classified to be a better performer in term of desired leaf traits. Accession NHGB/09/108, NG/AO/08/04 and NGB 01261 were grouped as better grain yield and yield attributes, while accession NGB 01234, NHGB 09/09 and NHAC3 have good grain and leaf yield. 


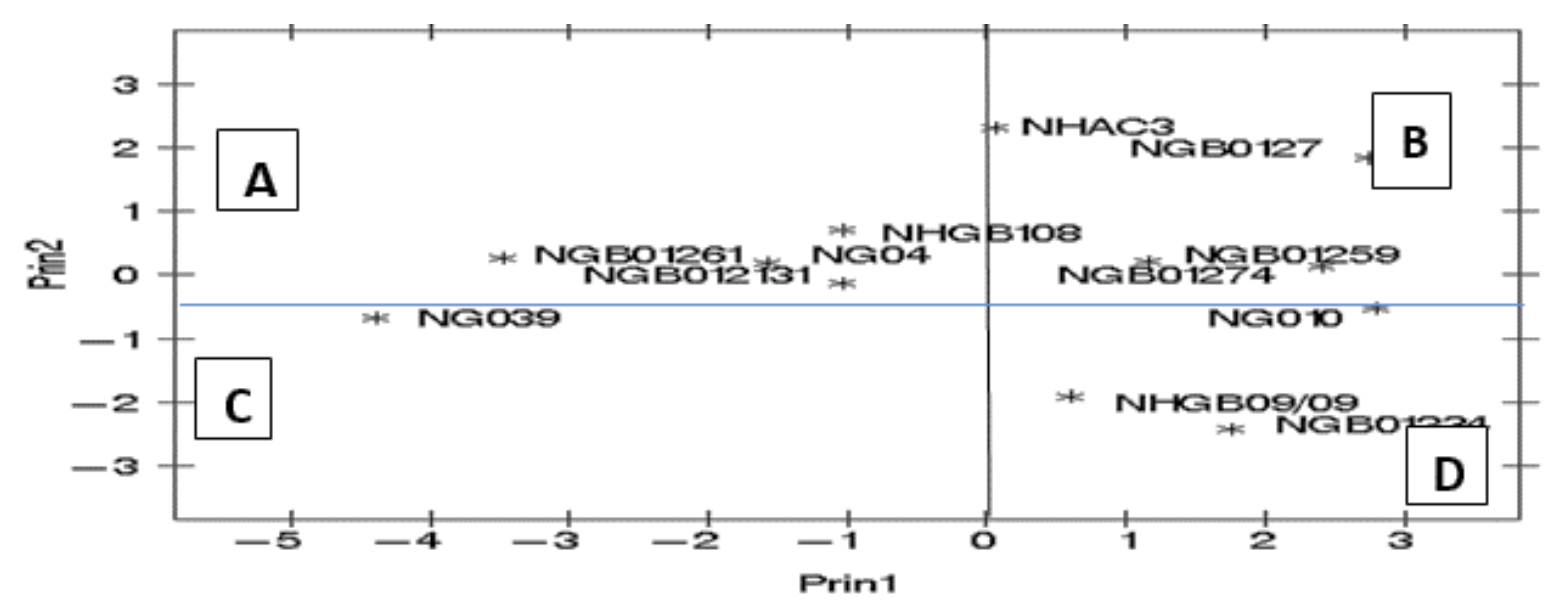

Fig 1. Bi-plot of PC2 vs. PC1 classifying 12 amaranth accessions

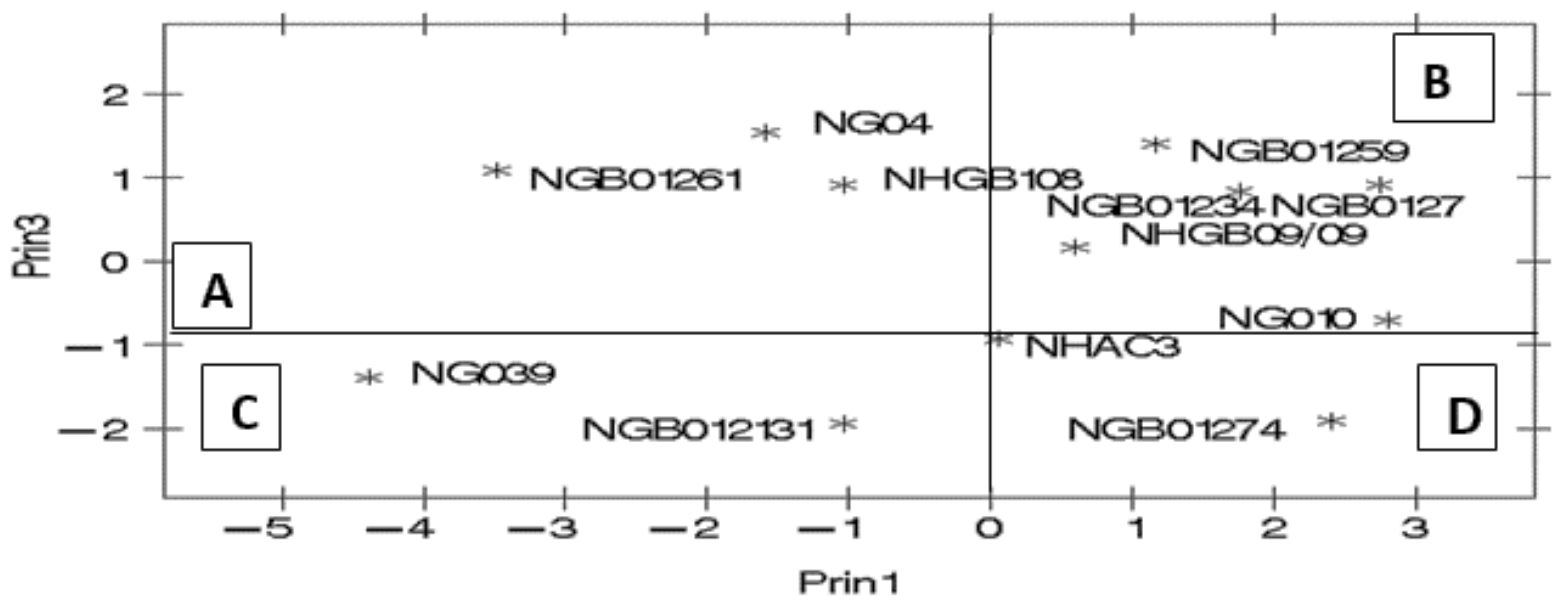

Fig 2. Bi-plot of PC3 vs. PC1 classifying 12 amaranth accessions

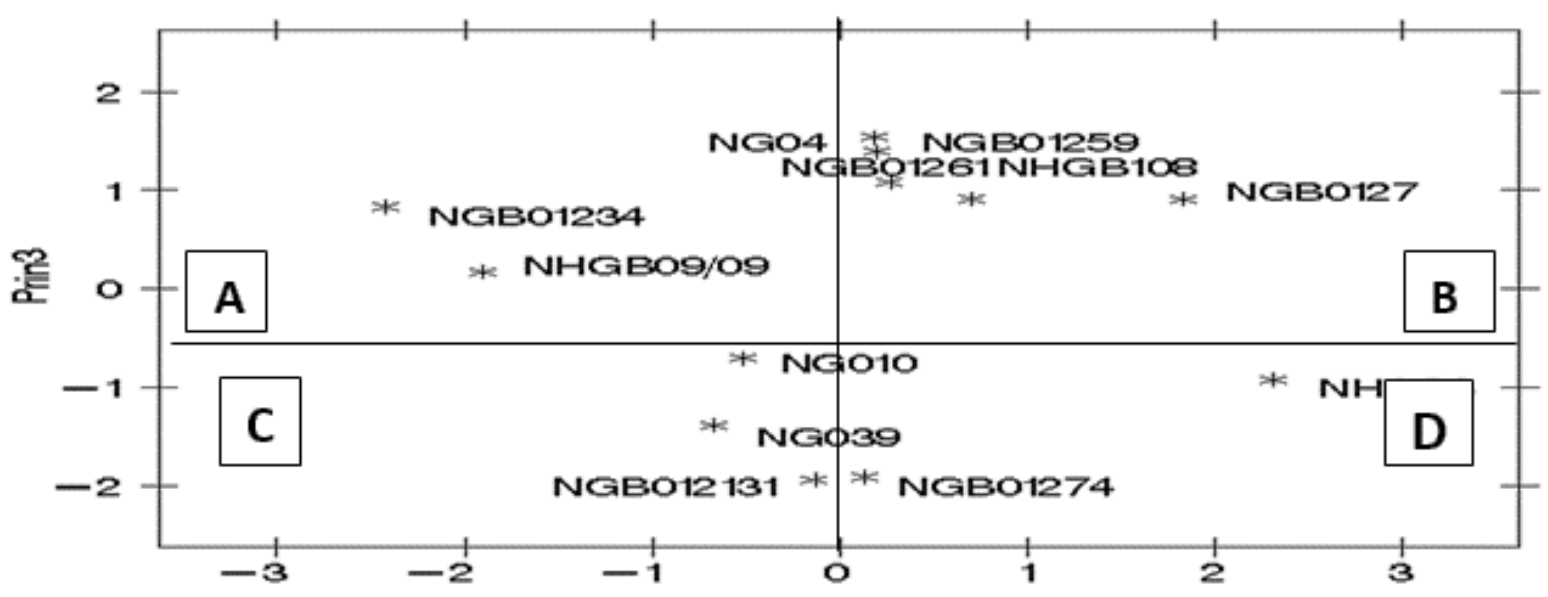

Fig 3. Bi-plot of PC3 vs. PC2 classifying 12 amaranth accessions 


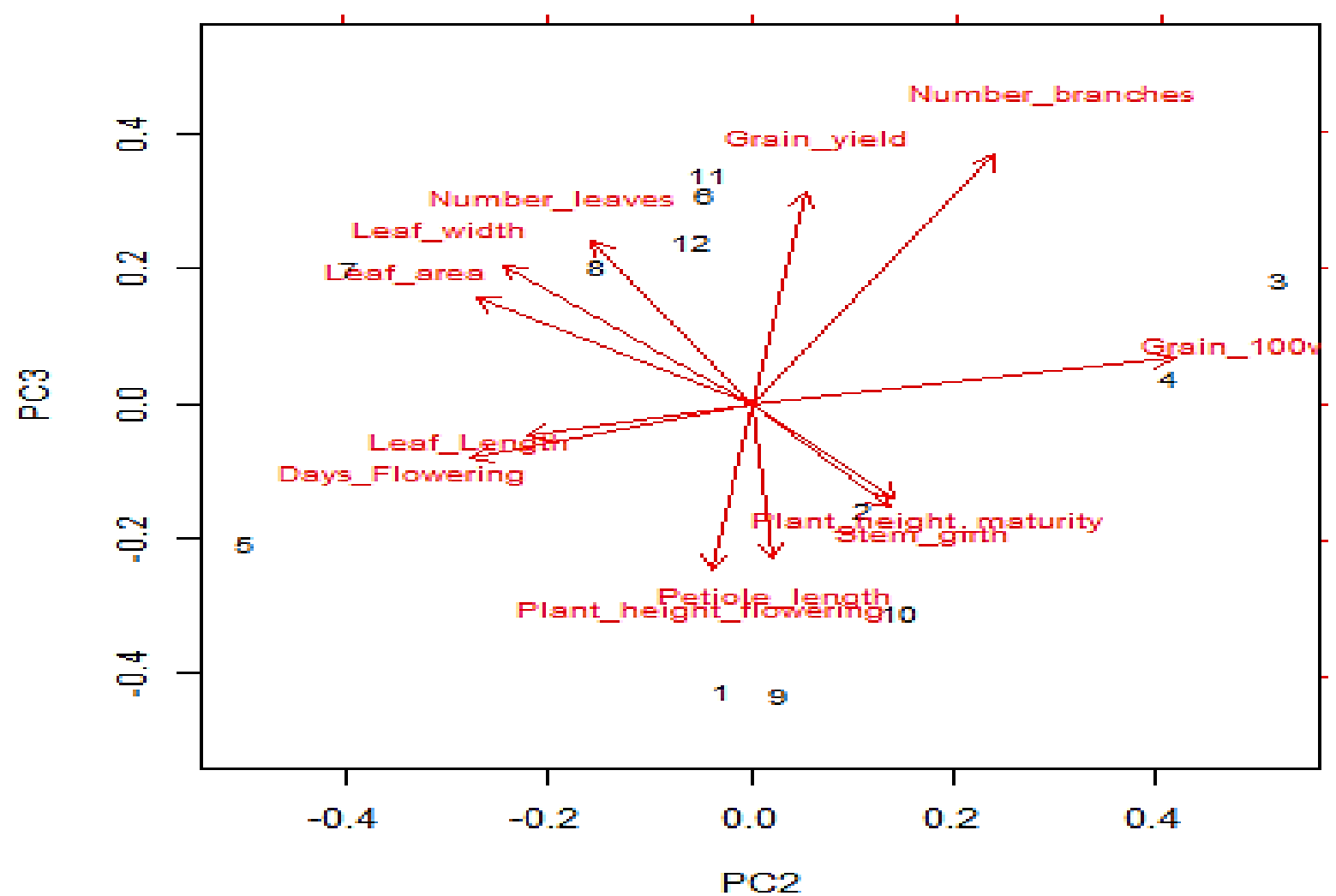

Fig 4. Classification of 12 amaranth accessions based on trait capture in PC3 vs. PC2

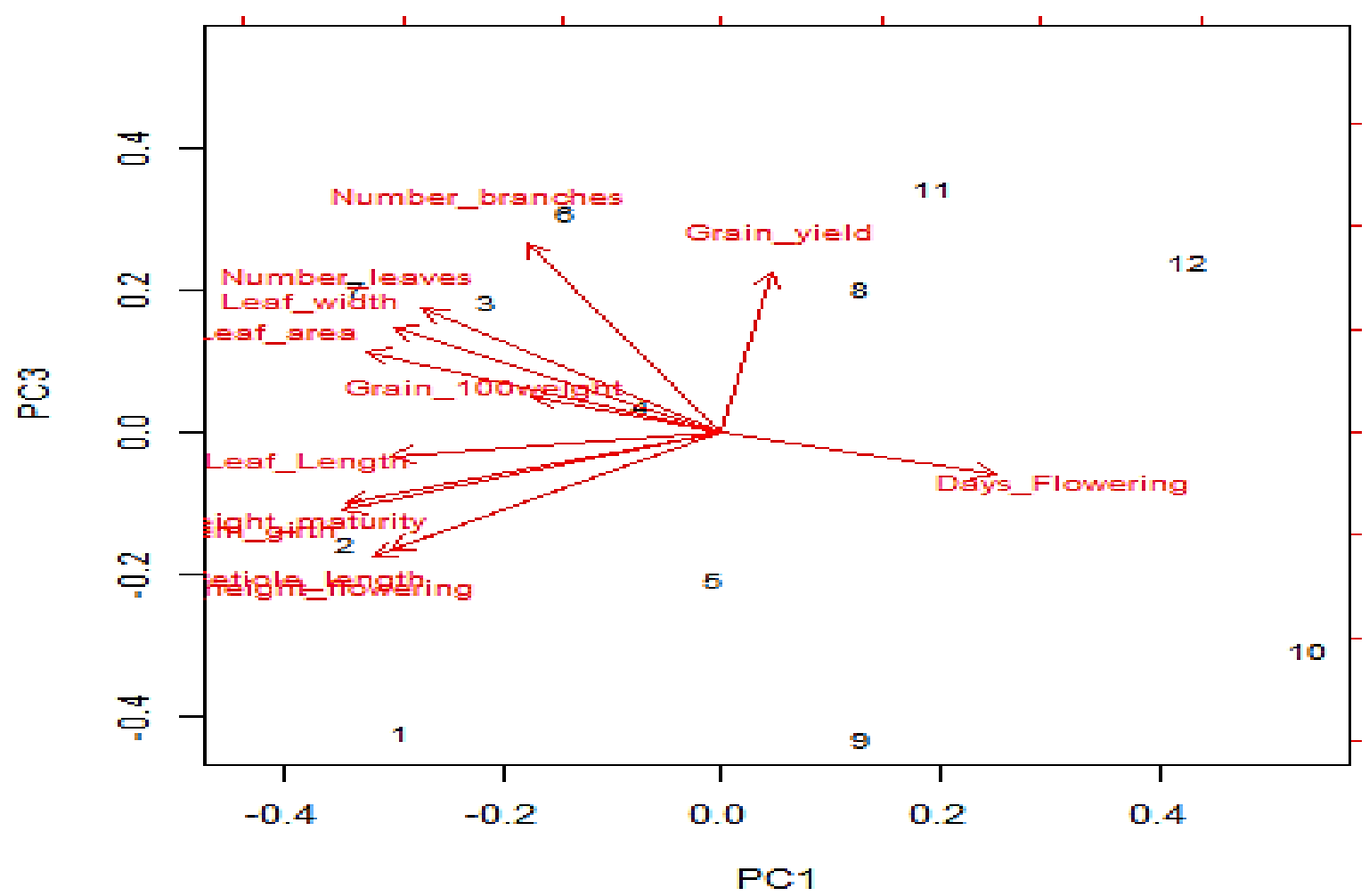

Fig 5. Classification of 12 amaranth accessions based on trait capture in PC3 vs. PC1 


\section{DISCUSSION}

The grain amaranth in this study exhibited high phenotypic and genetic variability in their significant response for all the traits measured, particularly the desired leaf traits and grain yield traits. This was also confirmed by the mean performances that also showed high variation among the accessions of grain amaranth. The variability in this study revealed that, these accessions can be improved using their genetic potentials in selection. This result agrees with the results of Ajala et al., (2003), Adebisi et al., (2004), Coastea et al.,(2001), Mahmood et al., (2013) who stated that useful variability in different crop varieties is helpful in selection. The performance result of the accessions shows that NGB 01234, NHGB 09/09, NHAC3, NHGB/09/108, NG/AO/08/04 and NGB 01261 had the best grain yield and yield attributes, while in term of leaf yield and desired leaf attributes, accessions NGB 01274, NG/AA/03/11/010, NGB 01259, NGB 0127, and NHGB/09/108 are outstanding from the other accessions.

The Phenotypic variances were slightly higher than the genotypic variance for all the traits measured. This suggests that environment had little influence on the traits studied for 2 years. Similarly, PCV is higher in magnitude than the GCV across the years of evaluations, the high difference between PCV and GCV obtained for all the traits studied is an indication of inherent variability for these traits and that there is the involvement of environmental factors or the contribution of non-additive gene effects. The heritability estimates for all the traits are moderate to high ranging from $41-69 \%$, this suggests that the genotypic aspect have more effect on the phenotypic performances of these traits, therefore, selection based on phenotypic performances of these traits will be reliable, effective and appropriate. All the desired leaf attributes; petiole length, leaf length, leaf width and Leaf area along with grain yield and 1000 grain weight are good predictors of grain amaranth accession performance. The high heritability estimate, GCV and GA obtained for grain yield/plot, 1000 grain weight, petiole length, number of leaves, number of branches, leaf area and leaf width are possibly controlled by additive gene action, thus, these traits can be improved through mass selection or pedigree method, Popa et al., (2010) worked on amaranth, Habtamu et al., (2011) worked on tef, Ayalneh et al., (2012) worked on tef and Gautam et al., (2017) worked on green pea presented similar result in their studies.

There is a very strong inherent association between grain yield with 1000 grain weight, leaf area, leaf length and leaf width. Similarly, all the leaf traits were strongly and positively correlated with each other, thus, these traits are a strong or major factor in relation to amaranth grain yield/plot and leaf yield/plot selection. The result of the traits correlations obtained in this study suggests that selection that is directed towards these traits will be efficient and effective in heavier grain weight, higher leaf yield and better grain yield improvement in grain amaranth accessions as also reported on garden pea by Sharma and Sharma (2013).

Principal component analysis (PCA) is a reliable method and a statistical approach to identifying major variance components also help in reducing the number of variables in the data collected in a breeding and selection process. Therefore, it saves time and resources and improves the selection responses in crop improvement programs (Johnson and Wichern 2007; Naroui Rad 2015 on melon). PCA also assist in determining the relationships between traits, and the independent principal components that are effective on plant traits, and in the evaluation of diversity (Beheshtizadeh et al., 2013; Georgieva, et al., 2016 on pea). The PCA identified all the 12 traits as important phenotypic traits; contributing to the overall traits variations, thus, good traits for amaranth selection and improvement. The strong association between PC1 and all the leaf attributes, PC2 and 1000 grain weight, and PC3 and grain yield indicated the possible selection direction. The first 4 PCs in this study were efficient in differentiating and explaining $78.06 \%$ of the grain amaranth accessions variation. The grouping or classification of the accessions indicated that accessions NG/AA/03/11/010, NGB 01259 and NGB 0127 are better than other accessions in leaf yield attributes, accessions NHGB/09/108, NG/AO/08/04 and NGB 01261 are classified as accessions with high grain yield, while accessions NGB 01234, NHGB 09/09 and NHAC3 are dual-purpose amaranth, thus, they can be useful as a leafy vegetable and grain vegetables. However, accession NGB 012131 and NG/AO/11/08/039 are not outstanding in term of general performance and the bi-plots classified them so. Earlier reports on classification by (Pal and Singh 2013, Sharma and Sharma 2013) in garden pea, Henane (2013) in sesame and Naroui Rad et al., (2017) in melon agree with the results obtained here.

\section{CONCLUSION}

This study concluded that the inherent variability among the amaranths accessions is useful for selection and crop improvement purposes. The genotypic performance, variance and coefficient of variation components are indicators of variability among the test accessions for all the traits in this study. All the 12 traits studied accounted for $78.06 \%$ variation of the genetic diversity in the accessions evaluated. Grain amaranth accessions NG/AA/03/11/010, NGB 01259 and NGB 0127 are identified as better in leaf yield attributes and can be improved as leafy vegetable accessions. Accessions NHGB/09/108, NG/AO/08/04 and NGB 01261 are classified as high grain yield, while accessions NGB 01234, NHGB 09/09 and NHAC3 are dual-purpose amaranth, thus, can serve as both grain and/or leafy vegetable amaranth.

\section{REFERENCES}

Adebisi, M. A., Ariyo, O. J., \& Kehinde, O. B. (2004). Variation and correlation studies in quantitative characters in soybean. The Ogun Journal of Agricultural Science, 3(1), 134-142.

Ajala, M. O., Adebisi, M. A., \& Akingbogun, D. A. (2003). Variability for seedling vigour in tropical cowpea (Vigna unguiculata L.Walp). Moor Journal of Agricultural Research, 4(1), 54-59.

Alam, A. M., Nadirah, T. A., Moshin, G. M., Saleh, M., Moneruzzaman, K. M., Aslani, F., Juraimi, A. S. \& Alam, M. Z. (2021). Antioxidant compounds, antioxidant activities and mineral contents among underutilized vegetables. International Journal of Vegetable Science, 27(2), 157-166.

Alegbejo, O. J. (2013). Nutritional value and utilization of Amaranthus (Amaranthus spp.)- A review. Bayero Journal of Pure and Applied Sciences, 6(1), $136-143$.

Allard, R. W. (1960). Principle of plant breeding (pp. 48-57). John Wiley and Sons Ltd Co, New York.

Amfo, B., \& Ali, E. B. (2021). Technology adoption by indigenous and exotic vegetable farmers, International Journal of Vegetable Science, $27(2), 105-119$.

Ayalneh, T., Habtamu, Z., \& Amsalu, I. (2012). Genetic variability, heritability and genetic advance in tef (Eragrostis tef (Zucc.)Trotter) lines at Sinana and Adaba. International Journal of Plant Breeding \& Genetics, 6(1), 40-46.

Babalola, O. O., Tugbobo, O. S., \& Daramola, A. S. (2010). Effect of Processing on the Vitamin C Content of Seven Nigerian Green Leafy Vegetables. Advance Journal of Food Science and Technology, 2(6), 303-305.

Beheshtizadeh, H., Rezaie, A., Rezaie, A. \& Ghandi, A. (2013). "Principal component analysis and determination of the selection criteria in bread wheat (Triticum aestivum L.) genotypes." International Journal of Agriculture and Crop Sciences 5(18), $2024-2027$.

Burton, G. W. (1952). Quantitative inheritance in grasses. Proceeding of $6^{\text {th }}$ International grassland Congress, 1, $277-283$. 
Coastea, M., \& Demason, D.A. (2001). Stem morphology and anatomy in Amaranthus L (Amaranthacea), Taxonomic Significance. Terry Botany 128(3), 254-281.

Coastea, M., Weaver, S.E., \& Tardif. F.J. (2004). The biology of Canadian weeds. 130. Amaranthus retroflexus L., A. powellii S. Watson and A. hybridus L. Canadian Journal of Plant Science, 84(2), 631-668.

Denton, L., \& Olufolaji, A. O. (2000). Nigeria's most important vegetable crops (pp. 85-93) in: Agronomy in Nigeria, M. O. Akoroda (ed), University of Ibadan.

Falconer, D.S. (1981). Introduction to quantitative Genetics (pp. 78-82). $2^{\text {nd }}$ edition, Longman Group LTD. London.

FAO. (2020). Fruits and Vegetables-your dietary essentials (81p). The International Year of Fruits and Vegetables, 2021, background paper. Rome.

Gautam, K. K., Syamal, M. M., Singh, A. K., \& Gupta, N. (2017). Variability, character association and path coefficient analysis of green pod yield and its related traits in pea (Pisum sativum L.). Legume Research, 40(5), 818-823.

Georgieva, N., Nikolova, I., \& Kosev, V. (2016). Evaluation of genetic divergence and heritability in pea (Pisum sativum L.). Journal of BioSci. \& Biotechnol., 5(1), 61-67.

Habtamu A., Tsige G., Tadesse D. and Landuber W. (2011). Multivariate, diversity, heritability and genetic advance in Tef landraces in Ethiopia. African Crop Sci. Journal, 19(3), 201-212.

Henane, I., Mezghani, N., Tlili, I., Rhim, T., Ghezal, I., Arfaoui, K., \& Jebari, H. (2013). Agro-morphological characterization and assessment of variability in local germoplasm of Cucumis melo L. in Tunisia. Journal of Biodiversity and Environmental Sciences, 3(12), 198207.

Johnson, R. A., \& Wichern, W. D. (2007). Applied multivariate statistical analysis (pp. 45-60). Prentice-Hall, Upper Saddle River, New Jersey.

Mahmood, T., Bilal, M., Khan, M.,A., Shabbir, Gh. \& Arif, M.S. (2013). Genetic variability and character association studies in spring and autumn sown Sunflower. International Journal of Agriculture and Biology, 15(2), 301-306.

Naroui Rad, M., R., Koohkan, S., Fanaei, H. R., \& Pahlavan Rad, M. R. (2015). Application of Artificial Neural Networks to predict the final fruit weight and random forest to select important variables in native population of melon (Cucumis melo L.). Scientia Horticulturae, 181, 108-112.

Naroui Rad, M. R., Fanaei, H. R., \& Galandarzehi, A. (2017). Integrated selection criteria in melon. International Journal of Vegetable Science, 23(2), 125-134

Nwangburuka, C. C., Kehinde, O. B., Ojo, D. K., Denton, O. A., \& Popoola, A. R. (2011). Morphological classification of genetic diversity in cultivated okra, Abelmoschus esculentus (L) Moench using principal component analysis (PCA) and single linkage cluster analysis (SLCA). African Journal of Biotechnology, 10(54), 11165-11172

Olufemi, B. E., Assiak, I. E., Ayoade, G. O., \& Onigemo, M. A. (2003). Studies on the effect of Amaranthus spinosus leaf extract on the Hematology of growing pigs. African Journal of Biomedical Research, 6(3), 149-150.

Olufolaji, A. O. (1996). Development of suitable agro-techniques for grain Amaranth production in Nigeria (pp. 6-16) In: National Training Workshop on grain Amaranth production and utilization organized by NIHORT August 7-8.

Pal, A. K., \& Singh, S. (2013). Assessment and genetic variability in garden pea (Pisum sativum L. var. Hortense). International Journal of Agric. Sci., 9(1), 293-296.

Popa, G., Cornea, C. P., Ciuca, M., Babeanu, N., Popa, O., \& Marin, D. (2010). Studies on genetic diversity in Amaranthus species using the RAPD markers. Tom. 17(2), 280-285.

SAS, (2008). Statistical Analysis System. Version 9.2., SAS Institute Incorporation NC., USA

Saunders, R. M., \& Becker, R. (1983). Amaranthus: A potential food and feed source. Advances in Cereal Science and technology, 6(1), 357396.

Snezana, D. M., Marija, K., Danijela, R., Milena, S., \& Lidija, S. (2012). Assessment of genetic relatedness of the two Amaranthus retroflexus populations by protein and random amplified polymorphic DNA (RAPD) markers. African Journal of Biotechnology, 7331-7337.

Sharma, B. B., \& Sharma, V. K. (2013). Genetic variability, heritability and genetic advance studies in garden pea under mid hill conditions of Garhwal Himalaya, Environ. Ecol.,31(1), 296-301.

Singh, R. K., \& Chaudhary, B. D. (1985). Biometrical methods in quantitative Genetics analysis (pp. 110-123). New Delhi, Kalyani Publishers,

Yan, W., \& Kang, M.S. (2003). GGE Biplot analysis: A graphical tool for breeders, geneticists and Agronomist (pp. 34-40). CRC Press, Boca Raton, FL, USA

\begin{tabular}{|l|l|l|}
\hline Copyright: ( 2021 by the authors. Licensee EJAR, EKB, Egypt. EJAR offers immediate open access to \\
its material on the grounds that making research accessible freely to the public facilitates a more \\
global knowledge exchange. Users can read, download, copy, distribute, print or share a link to the \\
complete text of the application under Creative Commons BY-NC-SA International License.
\end{tabular}

